水文・水资源学 会誌 J. Japan Soc. Hydrol. \& Water Resour. Vol. 15, No. 2(2002) pp. 290-301

\title{
Dynamic Flood Routing in River Networks and Application to the Red River Basin, Vietnam
}

\author{
河川網におけるダイナミック洪水追跡とベトナムのレッド川流域への適用
}

\author{
Nguyen Le TUAN* Graduate School of Systems Engineering, Miyazaki University \\ グエン・リ・トゥアン \\ (宮崎大学工学研究科)
}

Satoru SUGIO**

杉尾 哲

\author{
Department of Civil and Environmental Engineering, Miyazaki University \\ (宮崎大学工学部)
}

In this paper, a model for simulating the development of flood flow in a river network is introduced and then is applied for a real network. The paper focuses on the mathematical modeling of unsteady open channel flow in river networks and constructing the model for simulation. The application of the model to the Red River basin, the largest basin in Northern Vietnam, is shown. The calibration process for the investigated network and discussion on the hydrological aspects from the results are emphasized. The paper also dealt with engineering facets of practical activities in the Red River basin, where flood control and effective management of water resources are significant tasks nowadays.

Key words : Dynamic flood routing, River network, Computational hydraulics, Mathematical modeling, Red River Delta, Vietnam

本論文は，河川網に扔ける洪水流出解析のためのモデルを構案し，そのモデルを実際の河川網に適用している．まず，河川網の 非定常開水路流の数理モデリング方法と計算方法を示している. モデルは, ベトナム北部最大のレッド川流域に適用している. 次 に，モテルキャリフレーションを行った後，解析によって検討対象河川網の水文学的特性を明らかにしている．また，レッド川流 域において洪水制御と水資源の管理は重要であり，本論文ではこれらの工学的一面も㭘尉している.

キーワード: タイナミック洪水追跡, 河川網, 計算水工学, 数理モデリンダ, レッド川デルタ, ペトナム

\section{I . INTRODUCTION}

The propagation of a flood wave in river networks and the associated change in timing or attenuation of the wave constitute an important topic in hydrology. In order to simulate the fluctuations of flow in river network where the bed slope is mild and flow regime is effected by not only floods at upstream locations but also tides of the sea, the dynamic one-dimensional unsteady flow model can be used. In other words, when the complete form of the Saint Venant equations is used for flow routing as well as flood routing, the routing model is known as a dynamic routing model Most of commercial and academic dynamic one-dimensional models are finite difference methods (Fread, 1993; Liggett, 1994; Nguyen and Tran, 2000). The solution based on an implicit finite difference scheme is considered as unconditionally stable (Liggett and Cunge, 1975; Abbott and Basco, 1989; Strelkoff and Falvey, 1993; Liggett, 1994) and thus it is usually preferred for engineering applications (Cunge et al. 1980). Among many implicit finite difference schemes, the Preissmann scheme is

\footnotetext{
*Graduate School of Systems Eng. Miyazaki Univ., Gakuen Kibanadai Nishi 1-1, Miyazaki, 889-2192 Japan

宮崎大学工学研究科 $=889-2192$ 宮崎市学園木花台西1-1

**Faculty of Engineering, Miyazaki Univ., Gakuen Kibanadai Nishi 1-1, Miyazaki, 889-2192 Japan

宮崎大学工学部 T889-2192 宮崎市学園木花台西1-1
} 
perhaps the most widely used one (Lai, 1986; Fread, 1998). For all these reasons, this scheme is selected to construct the model used in this study. When an implicit difference scheme is used, it always forms a large system of equations that must be solved simultaneously. The double-sweep method is now accepted as the most effective way to solve the system of nonlinear as well as linear equations (Abbott and Basco, 1989).

The Red River basin is the largest basin in Northern Vietnam. Floods in the river usually threaten Hanoi, the capital of Vietnam as well as the Red River Delta (Nguyen and Sugio, 2001a; Nguyen, 2000). Researches about the development of flood flow in the river network, the combination of floods from the Red River and its tributaries, and especially the variation in space and time of flood characteristics are necessary not only for flood control but also for real time operation of hydraulic structures in the basin. This research is expected to improve on those problems by introducing a model in which the initial conditions for river networks is set up conveniently. A procedure for generating initial condition is developed and improved from familiar method applied to a single reach.

\section{GOVERNING EQUATIONS AND SOLU. TION IN BRIEF}

In the viewpoint of computational hydraulics, a river network includes channel reaches, junctions where a channel meets another, and hydraulic structures that can be treated as internal boundaries.

The unsteady flow in an open channel is described by the Saint Venant equations, which consist of the continuity equation and the motion equation (Cunge et al., 1980; Lai, 1986; Fread, 1993, 1998). These equations are written as follows:

$$
\begin{aligned}
& \frac{\partial y}{\partial t}+\frac{1}{B} \frac{\partial Q}{\partial x}=q \\
& \frac{\partial Q}{\partial t}+\frac{2 Q}{A} \frac{\partial Q}{\partial x}-\left(\frac{Q}{A}\right)^{2} \frac{\partial A}{\partial x}+g A \frac{\partial y}{\partial x}+g A S_{f}=0
\end{aligned}
$$

where $t$ is time, $x$ is the distance along the channel, $Q$ is the discharge, $A$ is the wetted cross-sec- tional area, $y$ is the water surface level, $B$ is the wetted cross-sectional width, $q$ is the lateral inflow, $g$ is the gravitational acceleration and $S_{f}$ is the friction slope which can be evaluated using Manning's formula:

$$
S_{f}=\frac{n^{2} Q|Q|}{A^{2} R^{4 / 3}}=\frac{Q|Q|}{K^{2}}
$$

in which $n$ is the Manning's coefficient of frictional resistance, $R$ is the hydraulic radius and $K$ is the conveyance factor.

For other elements of a river network, two equations equivalent to the Saint Venant are required. For example, a compatibility condition must be satisfied at a junction and is described as:

$$
\begin{aligned}
& \sum_{k=1}^{m} Q_{k}=0 \\
& y_{1}+\frac{1}{2 g}\left(\frac{Q_{1}}{A_{1}}\right)^{2}=y_{2}+\frac{1}{2 g}\left(\frac{Q_{2}}{A_{2}}\right)^{2}=\cdots=y_{m}+\frac{1}{2 g}\left(\frac{Q_{m}}{A_{m}}\right)^{2}(5)
\end{aligned}
$$

where $m$ is the total of the links which emanate from the junction, and $Q_{k}$ is the discharge of the $k$ -th link.

If there is a sudden change in cross sectional area at a location in river reach, it is treated as an internal boundary in computation. Two proper compatibility conditions are (Cunge $e t$ al , 1980):

$$
\begin{aligned}
& Q_{1}=Q_{2} \\
& y_{1}+\frac{u_{1}^{2}}{2 g}=y_{2}+\frac{u_{2}^{2}}{2 g}+f \frac{\left(u_{1}-u_{2}\right)^{2}}{2 g}
\end{aligned}
$$

where the energy loss coefficient $f$ would be variable, depending on the flow direction for example. The subscripts 1 and 2 in equations (6) and (7) indicate the two cross sections described the location where the sudden change occurred.

In the case of hydraulic structures, these two equations are established from the assumption that the discharge values at two cross sections; just upstream and downstream of the structure, are the same and an empirical relationship for computing discharge through the structures (Cunge et al . 1980; Fread, 1998).

Equations (1) and (2) can be solved numerically by approximating them with a set of finite difference algebraic equations. In this study, the widely used Preissmann implicit finite difference scheme is applied. The system of equations after approxi- 
mating is nonlinear and can be solved by iterative methods in which the nonlinear equation system is usually first linearized. For the purpose of linearization, the Taylor series expansion can be used (Liggett and Cunge, 1975; Cunge et al. 1980; Abbott and Basco, 1989). In this way, the equations expressed in finite difference for a $\Delta x$ river reach from cross section $j$ to cross section $j+1$ can be written as follows:

$$
\begin{aligned}
& A_{1} \Delta y_{j+1}+B_{1} \Delta Q_{j+1}+C_{1} \Delta y_{j}+D_{1} \Delta Q_{j}+G_{1}=0 \\
& A_{2} \Delta y_{j+1}+B_{2} \Delta Q_{j+1}+C_{2} \Delta y_{j}+D_{2} \Delta Q_{j}+G_{2}=0 \text { (9) }
\end{aligned}
$$

where $\Delta y$ and $\Delta Q$ are increments of water surface elevation and discharge during the time step $\Delta t$, respectively. $A_{1}, B_{1}, \ldots, G_{2}$ can be computed from the known values of $Q$ and $y$ at the previous time step.

Any efficient technique for this equation system is desired for practical applications, and the double -sweep method is the one of these techniques. This method is very convenient as it dispenses with all matrix operations (Montes, 1998).

In the double-sweep method, the following linearized approximation is introduced:

$$
\Delta Q_{j}=E_{j} \Delta y_{j}+F_{j}
$$

which is inserted into the difference equations (8) and (9), yielding.

$$
\Delta y_{j}=L_{j} \Delta y_{j+1}+M_{j} \Delta Q_{j+1}+N_{j}
$$

As its name, the double-sweep method includes two "sweeps" along a river reach. The first sweep is a forward sweep or elimination sweep and the second sweep is a backward sweep or substitution sweep. In other words, there are two steps in the calculation process. In the first step, the coefficients $E, F, L, M, N$ are calculated for all cross sections (computational points) of the reach, and then the unknown values of $Q$ and $y$ are obtained by back substitution in the second step (Liggett and Cunge, 1975; Lai, 1986; Abbott and Basco, 1989; Montes, 1998).

In the case of dendritic or branched river networks, the double-sweep method can be applied with some modifications. The main problem for these types of networks is to determine the order for elimination in the forward sweep. This can be solved by using the graph theory (Nguyen and
Sugio, 2001b). The river network is described by nodes and branches, and then two lists (list of nodes and list of branches) are formed. From these two lists, a procedure for searching the unique node and removing the corresponding reach in the list of branches is implemented. It is an alternative process that to be repeated until the list of branches becomes empty. After performing the procedure, another list is constituted. This list will control the order of elimination sweep. This method of treatment for a river network essentially considers the network as a special river reach with special cross sections. Physical connections at a junction are treated as nodes and their close cross sections in simulation. Therefore, from this idea it can be said that all of the effectiveness of double-sweep method for a single river reach can also be inherited in the case of river networks. With the improvement, the double-sweep method can be applied to any branched networks regardless of the maximum order of a branch, i.e., the maximum level of tributary in the network as defined by Strahler (Scheidegger, 1970), as well as the number of branches at a junction.

\section{PROCEDURE FOR GENERATING IN- ITIAL CONDITIONS}

The solution of the dynamic flow routing model can be obtained only when boundary conditions and initial conditions are supplied to the model. Determining the initial conditions for the model, easily, quickly, and validly, specially in the case of river networks, can make the model more applicable in practical engineering. It is also possible because of large number of computational point.

The known values at all computed points when starting simulation $(t=0)$ are called initial conditions. Because not only water levels but also velocities and discharges have to be measured at the same time, measuring of initial data becomes an impossible task in real practices. As a rule, initial data must be assumed with some degree of approximation (Cunge et al, 1980). In the general case of flood routing, it can be said that as time progresses the information transmitted through 
the boundaries becomes more and more important as compared to the initial state whose influence on the solution is progressively damped through friction. After a period, say time $t_{1}$, the "memory" of the initial state is lost to the system. Thus, in the solution for $t>t_{1}$, the initial state can be quite inaccurate as it will not influence the solution. This permits the initial conditions to be approximated without loss of accuracy in the solution (Cunge et al. 1980). The initial condition may be obtained from any of following: $(i)$ observations at gauging stations, or interpolated values between gauging stations for intermediate cross sections in large river, (ii) computed values from a previous unsteady flow solution; and (iii) computed values from a steady flow backwater solution. The backwater method is most commonly used (Fread, 1993). This paper concentrates on the problem of setting out the initial conditions for a river network.

As mentioned above, the double-sweep method is the best selection for solution of one-dimensional dynamic flow routing in a river network where there are many computational points, up to hundreds or thousands, with long time floods.

By using the procedure for determining the order of the sweeping process in dendritic river network, the list is finally yielded. It has the order of node $\rightarrow$ river reach $\rightarrow$ node $\rightarrow$ node $\rightarrow$ river reach $\rightarrow$... $\rightarrow$ node. In other words, it tells the model which node to be eliminated first, which to be eliminated next, and where to stop eliminating and transfer to the substituting process (Nguyen and Sugio, 2001b). This list of order is also used for generating the initial conditions.

For a river reach, the discharge $Q$ from a computed point $j$ to $j+1$ can be calculated as:

$$
Q_{j+1}=Q_{j}+q_{j} \Delta x_{j}
$$

In the backwater method, values of water level can be calculated based on the gradually varied flow equation (Henderson, 1966; Fread, 1993; Montes, 1998):

$$
\frac{d y}{d x}=\frac{S_{0}-S_{f}}{1+\alpha d\left(v^{2} / 2 g\right) / d y}
$$

where $\mathrm{v}$ is flow velocity, $S_{0}$ is the bed slope of the river reach and $\alpha$ is the energy coefficient.

For a river network, generating procedure of the initial conditions includes two steps. The first step is to calculate the discharge of all river reaches using the equations (12) and (4) from boundary conditions at $t=0$. The second step is to calculate the water level of river reaches using the backwater method and equation (5).

In the first step, the discharge will be set up from a known discharge at the node. In practice, there is the fact that not all the nodes in a river network have measured discharge values. Thus, in this research it requires some arbitrary assumptions. Depending on the list controlled the sweeping processes, the procedure will check all the nodes where a discharge value is available and then calculate the discharge value of all unknown points in a river reach. For the remaining reaches, the procedure will automatically estimate the discharge values based on wetted cross sectional area proportions at the mean level of the first corresponding cross sections of the reach. The mean level is estimated as the average value of maximum and minimum levels of cross section data that have been supplied as input configuration information of the river network. For example, a simple river network is considered as Fig. 1.

In order to calculate the initial conditions for all

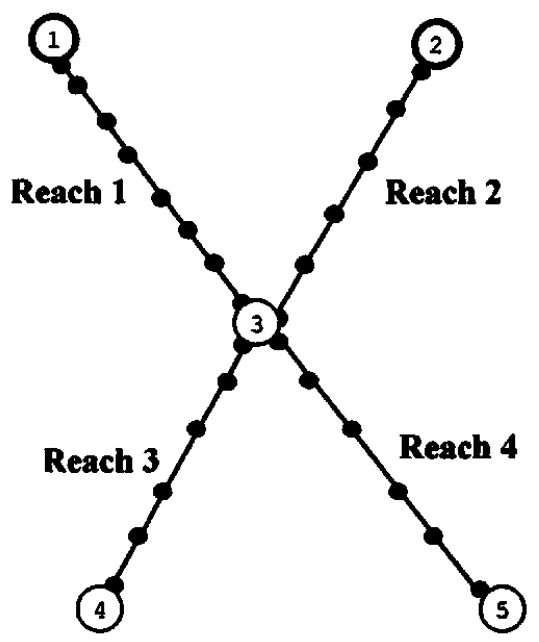

Fig. 1 Example of determining discharge values for river network 
computational points of this network, discharge and water level must be known at some of nodes $1,2,4$, and 5 as boundary conditions. For the purpose of explaining a specific case, supposing that the discharge values at node 1 , node 2 and the water level of node 5 are available at the time of computation. In fact, there may be some cases other than that presented herein but the procedure is designed with the aim of simplicity in simulation. In practical computation, with the network shown in Fig. 1 for example, if a value of discharge or water level, or a rating curve at node 4 is available as a boundary condition, it will be disregarded. If it is used, it can lead a more complex situation in computation such as the conservation law of discharge or of energy at node 3 will not be satisfied. Once again, it needs to emphasize that the strictly theoretical reasonableness has not been touched on because the initial conditions can be approximated with some degree of error. In applications to a real world, they are even assumed as a constant water level and zero discharges for computational points (Cunge et al., 1980).

The discharges at nodes 1 and 2 , are denoted as $Q_{1}$ and $Q_{2}$, respectively; the wetted cross sectional area at mean level of the first cross section of reach 3 (from node 3 to 4 ) is $A_{31}$, and of reach 4 is $A_{41}$. The process of computing discharge values is:

-From $Q_{1}$, calculating all discharge values for all computed points in the reach 1 with the assumption of a steady state. Because of the small lateral discharge data in comparison with discharges from upstream, the lateral flows are not considered in this study, i.e. $q_{j}=0$ in equation (12). Thus the initial discharge value is the same along the river reach.

-From $Q_{2}$, calculating the discharge values for all computed points in the reach 2 .

-The discharge value at the first cross section of reach 3 is estimated as $Q_{3}=\left(Q_{1}+Q_{2}\right) \frac{A_{31}}{A_{31}+A_{41}}$ and from this value of $Q_{3}$ the reach 3 will then completed.

-Repeat the previous computation for reach 4

$$
\text { with } Q_{4}=\left(Q_{1}+Q_{2}\right) \frac{A_{41}}{A_{31}+A_{41}}
$$

In the second step, the water level will be calculated for all computed points of the river network with opposite direction. Supposing the water level at node 5 is available, the water levels of all points in reach 4 are calculated by the backwater method up to node 3 . At node 3 , the water level is calculated by utilizing equation (5) without the velocity head terms (i.e., the $v^{2} / 2 g$ term) in order to avoid an iterative operation. Then process will be carried out from node 3 to node 4 , from node 3 to node 2 , and finally from node 3 to node 1 .

In general, it can be said that the procedure for generating initial conditions has a high speed of convergence. For the investigated network, the iteration process will stop after 3-5 cycles with a small tolerance (e.g. $\varepsilon \leq 0.000001$ ). In special cases, this criterion is satisfied after about $20-25$ cycles. There is a fact that in the river reaches near the sea with a very mild slope that are effected strongly by tides, the iteration processes are longer. It is evident that the assumption of steady flow in these reaches with unvaried discharge in space is somewhat unrealistic. From the results, it can also be said that in a reach with a large discharge value and topographical properties which change strongly, the number of iteration cycles is large. This is a consequence of an unsteady river flow. The initial conditions influence to the results only in the beginning period. In the Red River network investigated here, this period is about $20-30$ hours.

\section{APPLICATION AND RESULTS}

\section{Study area and data}

The above procedure of generating initial conditions introduced here is used to simulate the flood flow in a part of Red River network as shown in Fig. 2. Floods of the Red River basin directly threaten Hanoi, the capital of Vietnam. The total length of the river reaches used in the computation is about $900 \mathrm{~km}$ and the area is about 6200 $\mathrm{km}^{2}$. Topography and hydrological data used in this study were measured by Hydrometeorological 

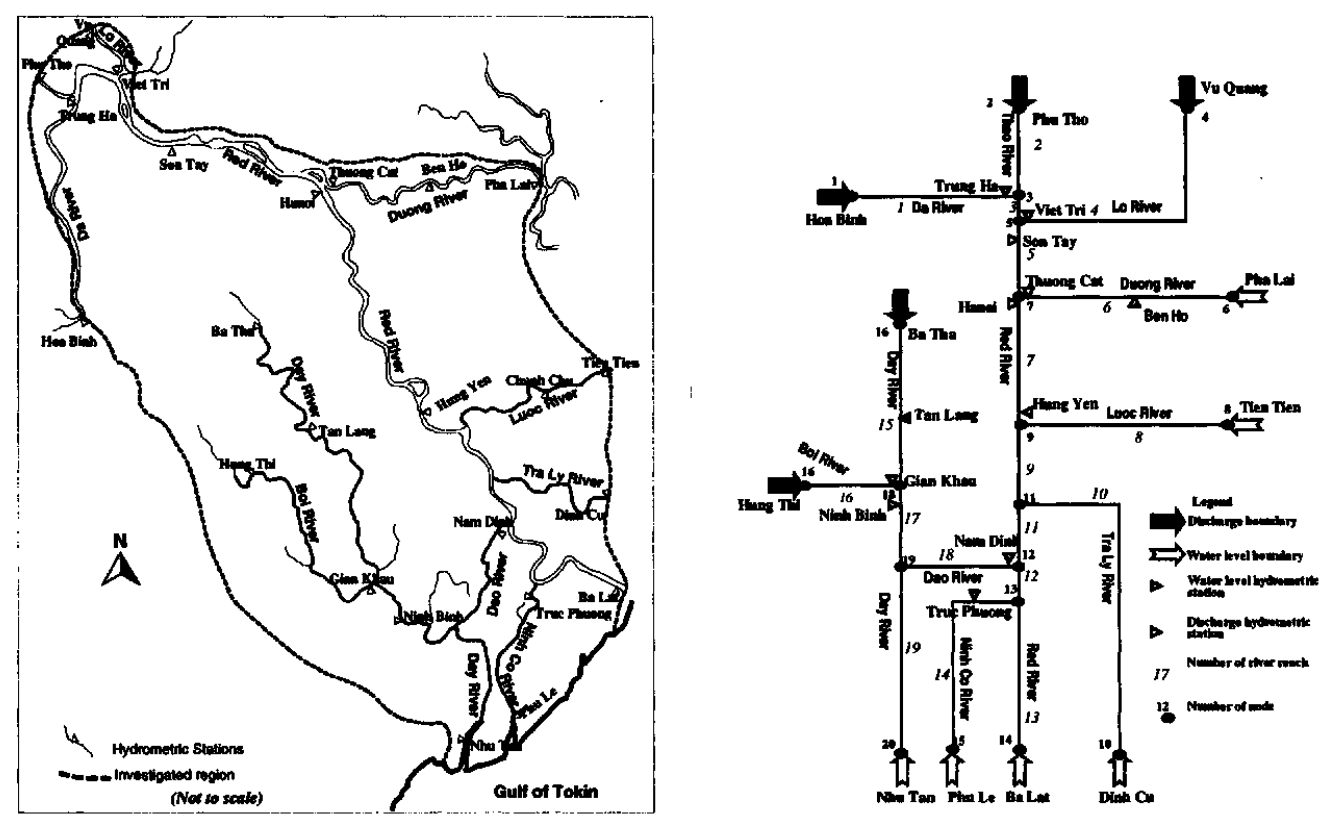

Fig. 2 Map of the investigated region and corresponding scheme for computation

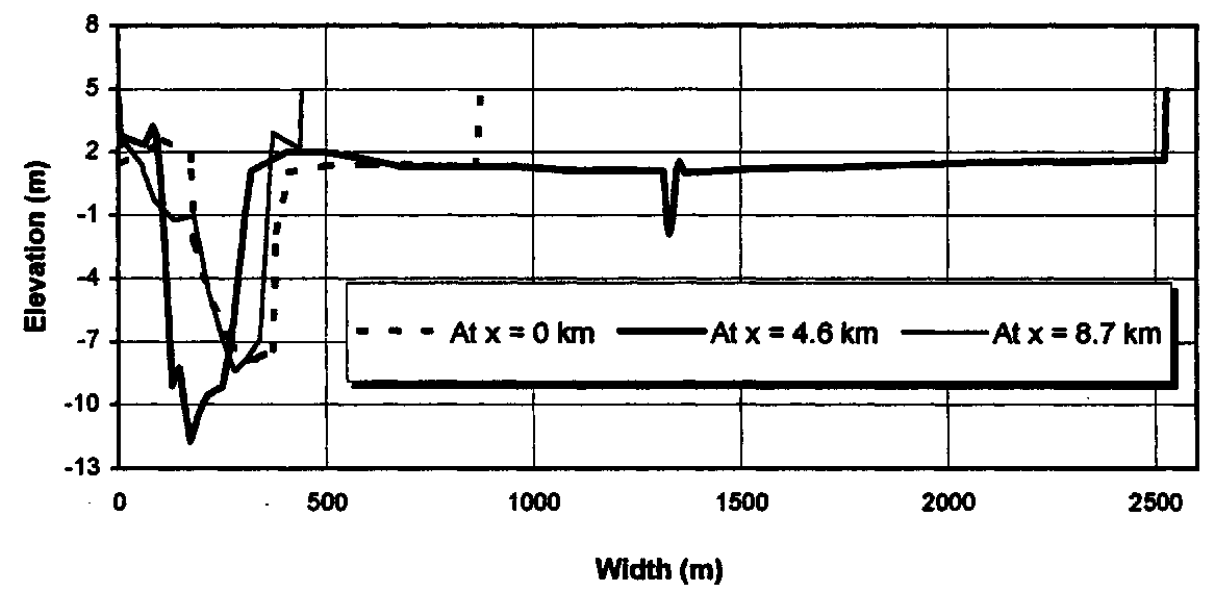

Fig. 3 Cross-section at some locations in the Dao River, from Ninh Binh to Nam Dinh

Service of Vietnam and Ministry of Agricultural and Rural Development of Vietnam (Nguyen, 2000). The topographical data were measured in 1992, 1997 and 1999. The typical shape of cross sections in the network is the same as the form of a compound section. The distance between a cross section and an adjoining one varies from $400-500 \mathrm{~m}$ to $3-4 \mathrm{~km}$. sometimes even up to $6 \mathrm{~km}$. The network is virtually dyked with extensive floodplains about $200-300 \mathrm{~m}$; as much as $2-3 \mathrm{~km}$ at some places (Fig. 3). A floodplain is a cultivated area. The cover conditions of the floodplain vary strongly in space and time. Using the criteria proposed by Ponce (1994), Fread (1993) and USACE 
(2000) along with field survey data, hydrological data and computational requirements from real engineering activities in the river network, show that a dynamic unsteady flow model is the most suitable method for flood routing in the Red River system (Nguyen, 2000).

\section{Results}

The large flood that occurred from August 9 to 30, 1996 in the Red River was used for the calibration of the model. Upstream boundary conditions used in calibration are given as observed discharge hydrographs at Hoa Binh, Phu Tho, Vu
Quang, Hung Thi and $\mathrm{Ba}$ Tha. The downstream boundary conditions are given as observed water level hydrographs at Nhu Tan, Phu Le, Ba Lat, Dinh $\mathrm{Cu}$, Tien Tien and Pha Lai (Fig.4). The roughness is a result of unsteady calibration. Thus, calibration process of the dynamic one-dimensional routing model is a process of adjusting the Manning's coefficient. This coefficient cannot be measured directly as it depends on several factors such as silting and erosion of sediments, bed forms, and vegetation. In the case that the width of floodplain is large, the adjustment of the roughness coefficient has to be done with an individual

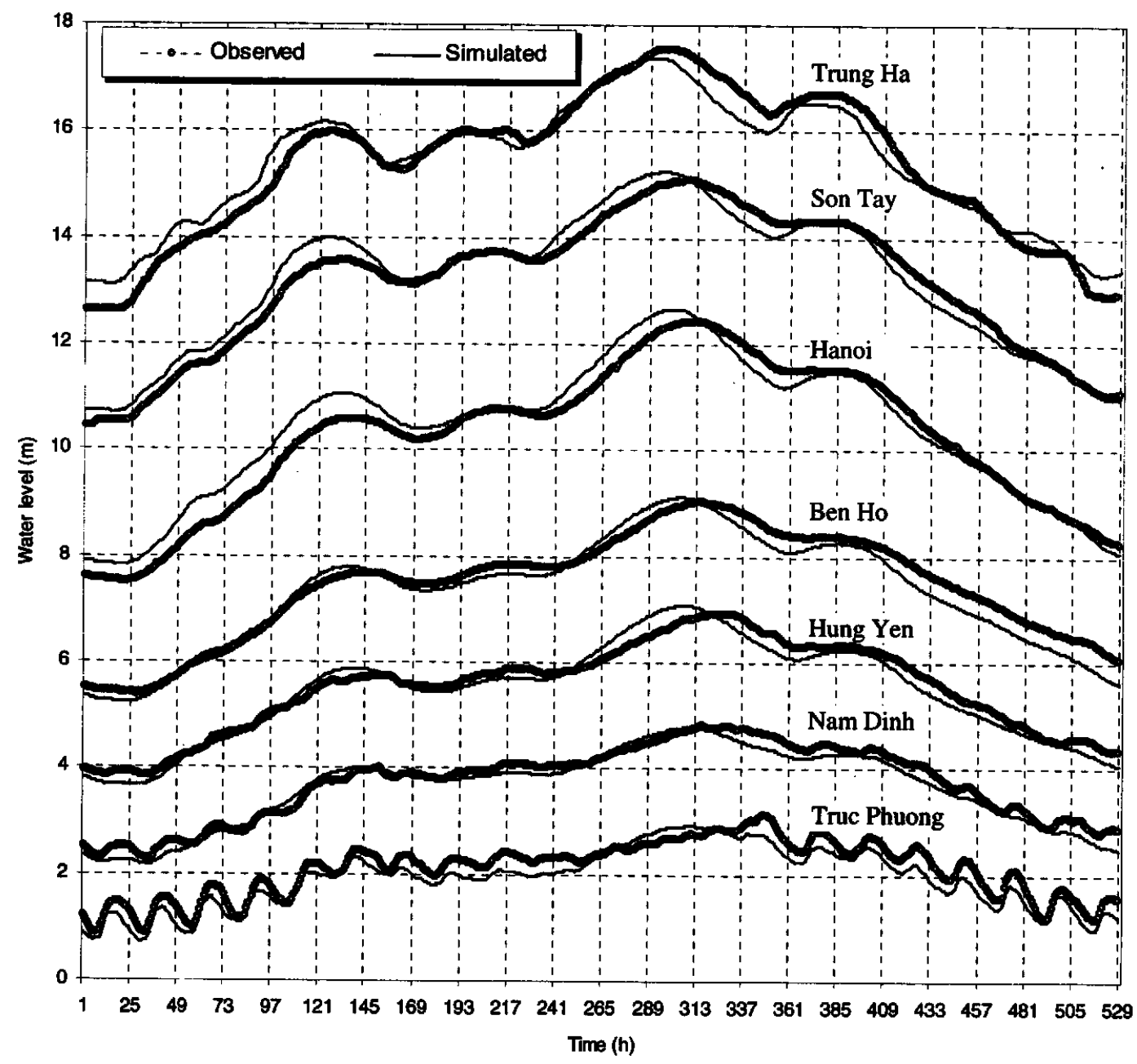

Fig. 4 Observed and simulated water level hydrograph along the Red River 
computed point or with group of computed points other than that for the whole river reach. In this study, the maps and field visits to the investigated area have been done in combination with the information from hydrometric stations in the network. In the simulated region, as well as in Vietnam, all hydrometric stations have the station's profiles, documented as "Descriptions about the station". This information is valuable not only for unsteady flow modelling but also for other research (Nguyen and Sugio, 2000). The cover conditions of the floodplain in the region differ from one location to the other but are similar in some successive cross sections. Therefore, in this study, instead of considering only one value of Manning's coefficient for a river reach, it is considered to be the same for some successive cross sections. There are two calibration approaches in literature: trial-and-error and automatic approach. The automatic approach is based on minimizing an objective function, such as, the sum of squares of the differences between observed data and numerically simulated values (Fread, 1998; Lebosse, 1992). In the case of a river network, the automatic approach seems more difficult for application because the error in one river reach can be accumulated and magnified throughout the whole network. Even now, success of the automatic calibration approach for a network is extremely rare. It is thought that the adjustment for a river network is more complex because of the reciprocal effects between river reaches. Because of all these reasons, the trial-and-error approach is used in this study.

The conveyance factor, the only factor that reflects effects of the roughness coefficient in the momentum equation, is computed according to the classical rules of hydraulics in which the total section conveyance can be considered to be the sum of conveyances in several subsections divided by vertical slides (Chow, 1959; Cunge et al., 1980; Montes, 1998). From the topographical characteristics of cross sections in the investigated river network, the conveyance of a section is computed separately for three parts: left floodplain, right flood-
Table 1 The values of Manning's $n$ for some types of floodplain cover condition and main channel

\begin{tabular}{l|c}
\hline \multicolumn{1}{c|}{ Location } & $\begin{array}{c}\text { The selected } \\
\text { values of } n\end{array}$ \\
\hline Floodplain & \\
Villages or residential areas & $0.070-0.160$ \\
Bamboo hedges & $0.045-0.100$ \\
Grass or cultivated area with cereals & $0.020-0.050$ \\
Fluvial bogs with sedges or jutes & $0.025-0.050$ \\
Main channel & \\
The Red River & $0.015-0.035$ \\
The Durong River & $0.015-0.040$ \\
The Dao River & $0.025-0.045$ \\
The Day River & $0.015-0.045$ \\
\hline
\end{tabular}

plain and main channel as follows:

$$
K=K_{t}+K_{\mathrm{c}}+K_{r}
$$

in which the subscripts $l, c$ and $r$ denote left floodplain, main channel, and right floodplain. Initial values and adjustments of $\mathbf{n}$ are based on field investigations and other guidelines (Chow, 1959; Yen, 1992). The selected values of $\mathbf{n}$ for typical types of floodplain cover condition as well as for main channel are shown in Table 1 . In this calibration, the values of $n$ are not out of the ranges presented in other researches (Nguyen and Sugio, 2000; Nguyen and Sugio, 2001b) but they have been refined at many locations of floodplains with information from the newer map of scale $1: 100000$. The values of $n$ can vary from tide ebb to tide flood because of the changes in the materials of sediment, but such variations are not yet explored in this study.

The observed and simulated water level hydrographs are shown in Fig. 4. The maximum error in peak water level is about $30 \mathrm{~cm}$, and the error in discharge is $5-12 \%$. However, the calibration process for the downstream region where the discharge data are not available is based on water level data. Therefore, it can be said that the computed discharge values in the downstream have a high level of uncertainty.

Fig. 5 shows the development of the flood wave in the main stream of the Red River from Hanoi to the sea. It can be said that the effect of the tide during this flood is reduced gradually within the 


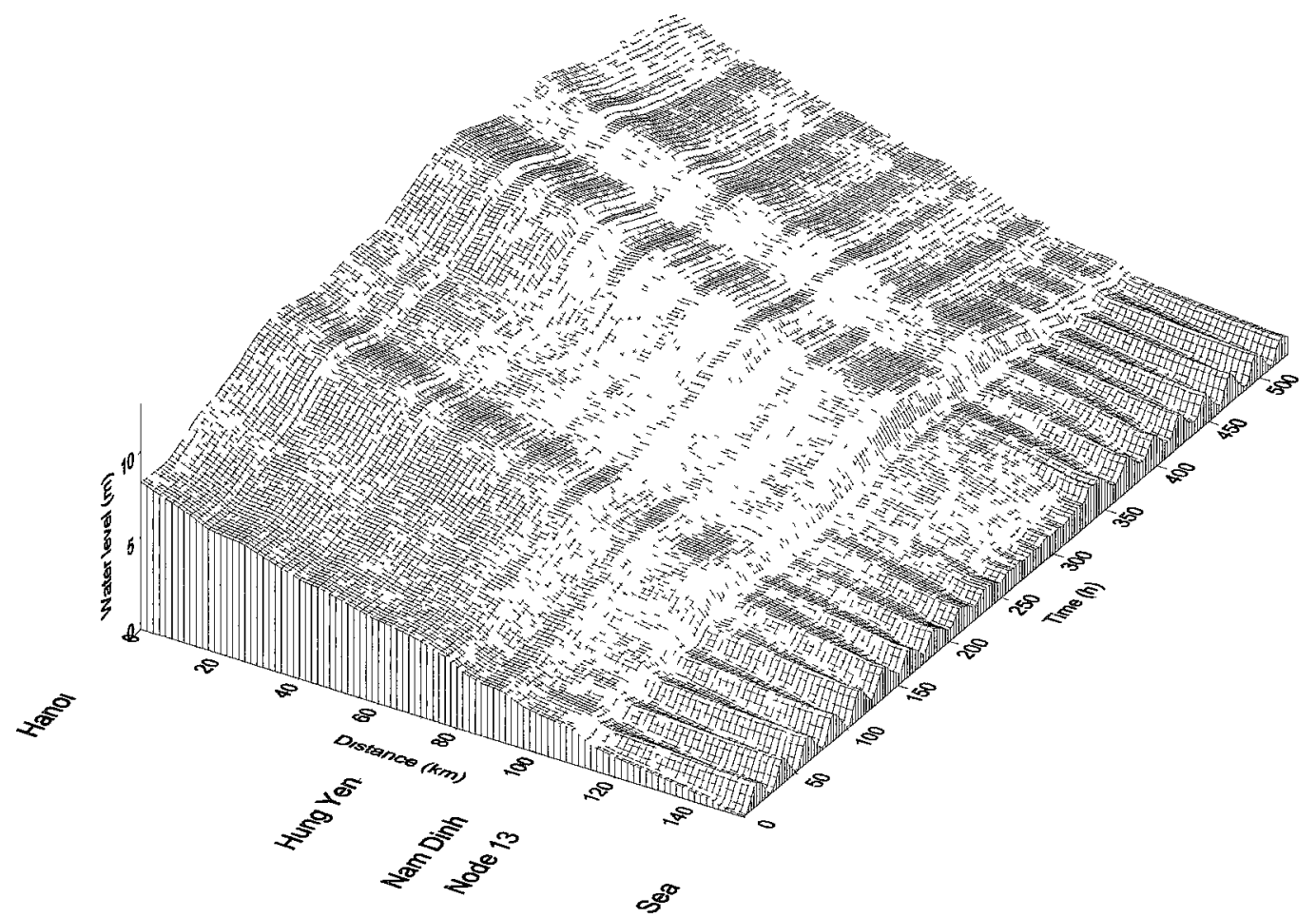

Fig. 5 Development of flood wave in the Red River from Hanoi to the sea

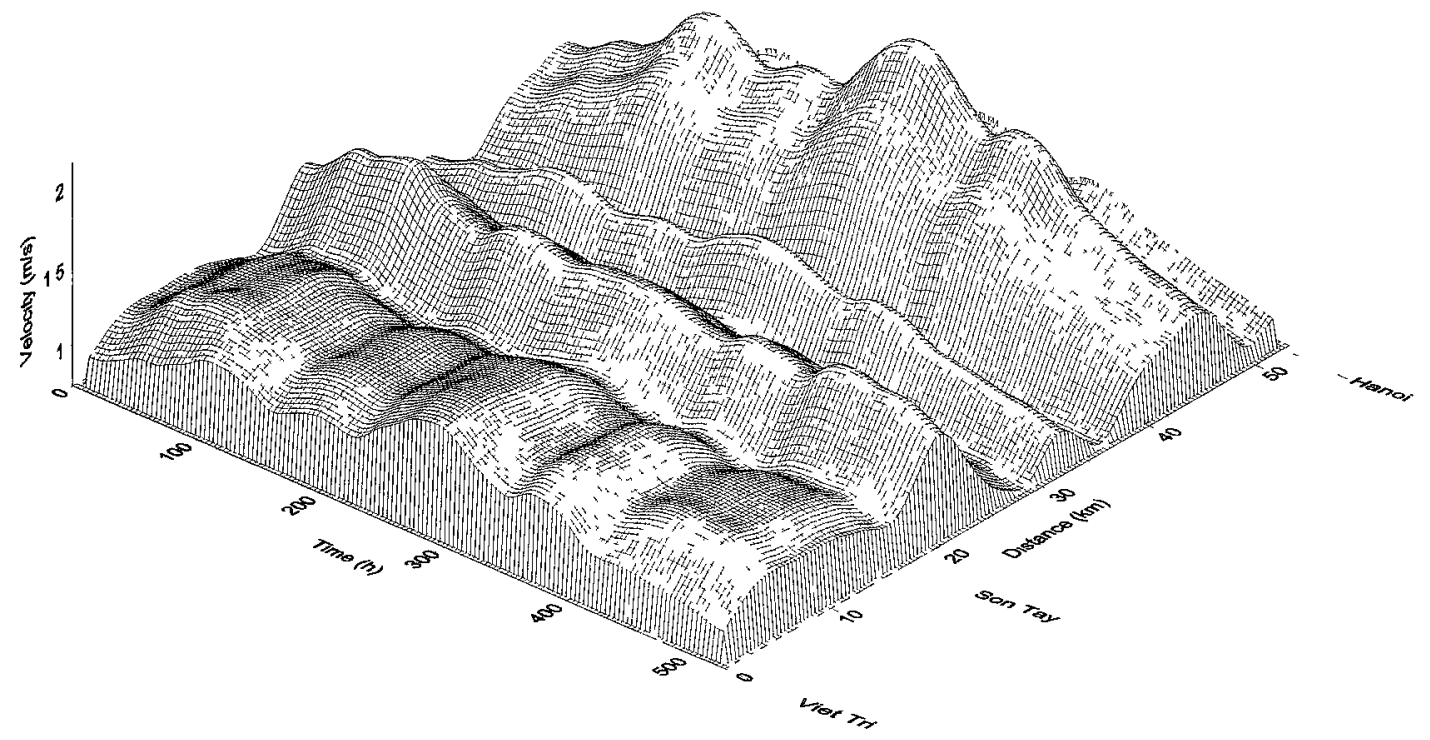

Fig. 6 Spatial variation of flow velocity in the river reach from Viet Tri to Hanoi 
river reach from Nam Dinh to the sea. This effect can be seen clearly in Fig. 5 in the last river reach of the Red River, which runs from node 13 to the sea (Fig. 2) with the length of about $35 \mathrm{~km}$. Fig. 6 shows the variation of flow velocity in the river reach from Viet Tri to Hanoi. In this reach, the cross sections are changed strongly, and as a result, the velocity is also changed strongly. Information about flow velocity can be used in river management as well as flood control projects. In this calibration, the distribution of total flow volume from August 9 to 30, 1996 along the main stream of the Red River and its tributaries is shown in Fig. 7. This figure shows that the Duong River and the Dao River are two main streams for diverting the flood from the Red River to other rivers and reducing the "tension" of flood in the Red River itself. However, as mentioned above, the measured discharge data are not available at downstream locations thus the results are limited. It is necessary to include data from other floods in order to introduce more reliable conclusions.

When a dynamic flood routing model is used for a river network, it does not only compute the discharge and water level at different cross sections, but also indicates the interactive relationship of river reaches in the network. Fig. 8 demonstrates

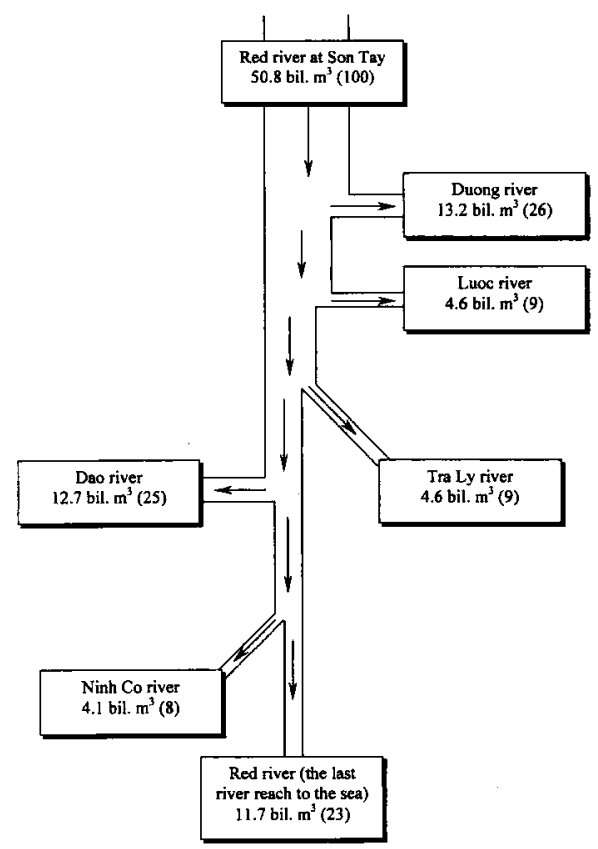

Fig. 7 Distribution of computed total flow volume of the flood from August 9 to 30 , 1996 along mainstream of the Red River from Son Tay to the sea

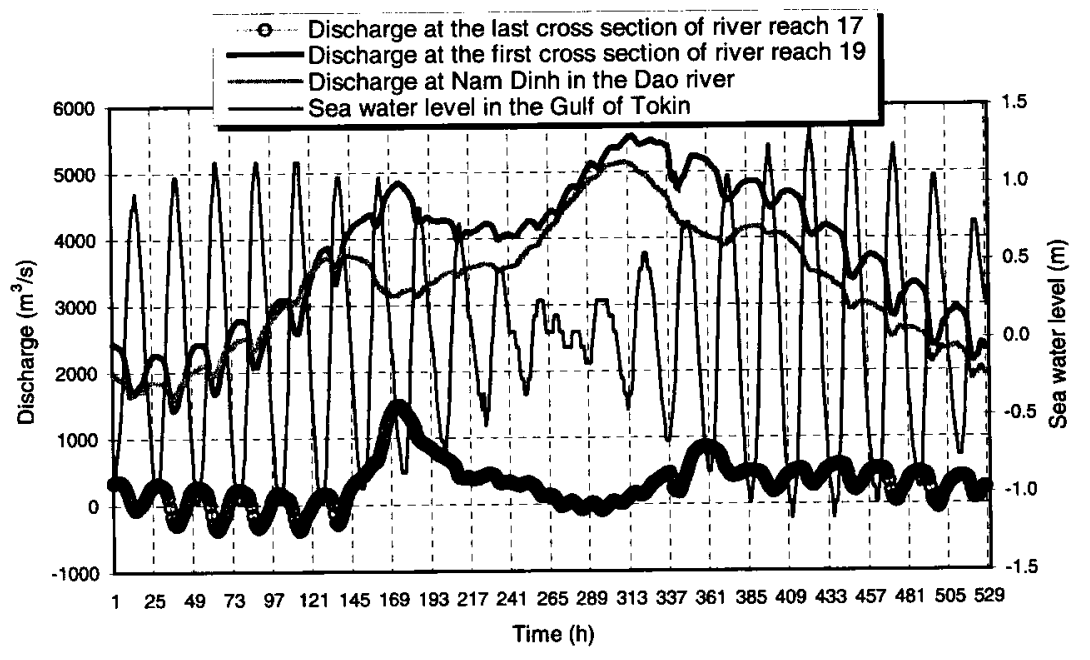

Fig. 8 Discharge hydrographs at Nam Dinh and two locations in the Day River 
the discharge hydrographs at the last cross section of river reach 17 and at the first cross section of river reach 19 in the Day River. Despite of the fact that two sites are close to each other, the flows are quite different. The discharge hydrograph of river reach 19 shows the effects of flooding and tide have on the flow. Flooding forms a trend of increasing discharge while the tide forms daily variations. The effects of flooding prevail over the period of the tide ebb (i.e, for example, the period from the time of 265 to 289 in Fig. 8). This explains the phenomenon of stagnant water and occasional flow of water to upstream in river reach 17. In this flood, the flow of the Day River is small in comparison with the flow from the Red River to the Day River through the Dao River. Thus, it causes the phenomenon. In other words, the complex effects of flood flow from the Red River to other rivers in the network can be considered and analysed numerically by the dynamic flood routing model.

\section{CONCLUSIONS}

This paper has introduced the dynamic one-dimensional unsteady flow model and its application to one part of river network of the Red River basin in Vietnam. From the results, the following conclusions can be drawn:

1. The model is a valid choice for study on the flood flow development in a river network where the flow regime is affected strongly not only by upstream flooding, but also by tides from the sea such as those of the Red River basin.

2 . For a river network, the procedure for generating initial conditions can be used together with the robust double sweep method in dynamic one-dimensional unsteady flow simulation in river networks. It can be said that when using unsteady flow for modelling flood flow in a river network, the initial conditions can be estimated by the simple but effective backwater method in combination with the Newton-Raphson technique.

3 . The roughness coefficient is the only adjust- able parameter in the model. Values of roughness coefficients determined in the calibration process proved that the roughness coefficient is a complex and fuzzy function of water depth and discharge. Thus it takes a lot of time to find out values of the parameter that can give results with acceptable errors. New calibration techniques should be explored.

4. The model can show not only the development of flooding in a river, but also the interactive relationships among rivers in the network. By the simulated flood of the model, it can be said that the work of flood prevention in the Red River faces the following difficulties: high water level and high flow velocity around the capital Hanoi, serious inundation in downstream region near the sea, as well as the risk of dyke breach or dyke overtopping.

5. The model is an useful tool for study on flood control and water resources management in the Red River basin. These are important tasks of engineering practices in Vietnam nowadays and also in the future.

However, the model needs to be developed continuously for other applications; such as low flow computation and effects of tides, the environmental aspects in the case of flood diversion, and effective control of hydraulics structures in the water resource system of the Red River basin.

\section{ACKNOWLEDGMENTS}

The authors would like to thank all the staff at the Hydrologic Research Center, Institute of Meteorology and Hydrology, Vietnam for their supplying the topographic and hydrological data of the investigated river network.

\section{REFERENCES}

Abbott, M.B., and Basco, D.R. (1989) : Computational Fluid Dynamics-An Introduction for Engineers, Longman Scientific \& Technical and John Wiley \& Sons.

Ankan, A.O., and Yen, B.C. (1981): "Diffusion wave flood routing in channel networks." $J$. of Hydra. Div, ASCE, 107 , pp. 719-732. 
Baase, S. (1988) : Computer Algorithms: Introduction to Design and Analysis, Addison-Wesley.

Booij, N. (1980) : Report on the ICES Subsystem FLOWS, Report No. 78-3, Delft University of Technology.

Choi, G.W. and Molinas, A. (1993) : "Simultaneous solution algorithm for channel network modelling." Water Resources Research, 29, pp. 321-328.

Chow, V.T. (1959): Open Channel Hydraulics, McGraw-Hill.

Cunge, J.A., Holly, F.M. Jr., and Verway, A. (1980) : Practical Aspects of Computational River Hydraulics, Pitman.

Fread, D.L. (1973): "Technique for implicit dynamic routing in river with tributaries." Water Resources Research, 9 , pp. 918-926.

Fread, D.L. (1993) : "Chapter 10 : Flow routing." Handbook of Hydrology, D.R. Maidment ed. McGraw-Hill, Chap. 10, pp. 10.1-10.36.

Fread, D.L. (1998): NWS FLDWAV Model: Theoretical Description, USA National Weather Service.

Henderson, F.M. (1966) : Open Channel Flow, Macmillan.

Joliffe, I.B. (1984): "Computation of dynamic waves in channel network." $J$. of Hydraulic Engineering, 110 , pp. 1358-1370.

Kanemoto, M., and Tsunematsu, Y. (1991): "Graph-theoretic analysis of gradually varies unsteady flows in river channel networks." $J$. of Hydraulic, Coastal and Environmental Engineering, JSCE, No. $429 / \mathrm{II}-15$, pp. $67-75$ (in Japanese).

Lai, C. (1986) : "Numerical modelling of unsteady open-channel flow.", Advances in Hydroscience, B. C. Yen, ed., 14, pp. 161-333.

Lebosse, A. (1992) : "Estimation of ManningStrickler roughness coefficient in Saint-Venant equations." Channel Flow Resistance-Centennial of Manning's Formula, B.C. Yen, ed., Water Res. Publ., pp. 436-450.

Liggett, J.A. (1994) : "Finite-difference method for shallow-water flow analysis." Computer Modeling of Free-Surface and Pressurized Flows, M.H. Chaudhry and L.W. Mays, eds., Kluwer Academic Publ., pp. 33-61.

Liggett, J.A., and Cunge, J.A. (1975) : "Chapter 4: Numerical method of solution of the unsteady flow equations." Unsteady Flow in Open Channels, K. Mahmood and V. Yevjevich, eds., Water Res.
Publ, 1, pp. 89-182.

Montes, J.S. (1998): Hydraulics of Open-Channel Flow, American Society of Civil Engineers (ASCE) Press.

Nguyen, L.T. (2000) : "The suitability of some shortened hydraulic methods for calculating flood wave propagation on the Red River System." Scientific and Technical Hydrometeorological Journal, 478, pp. 36-43 (in Vietnamese).

Nguyen, L.T, and Sugio, S. (2000) : "Calibration of dynamic one-dimensional unsteady flow model for flood routing in river networks." Sustainable Water Resources Management: Issues and Future Challenges, A.D. Gupta, ed., APD-IAHR, 1: Riverine hydraulics, pp. 55-63.

Nguyen, L.T., and Sugio, S. (2001a) : "Flood control measures in the Red River basin and numerical simulation of their operations." Integrated Water Resources Management, M.A. Marino and S.P. Simonovic, eds., IAHS Publ. No. 272, pp. 341-348.

Nguyen, L.T., and Sugio, S. (2001b) : "Numerical solution with graph theory for flood flow in river networks." Annual Journal of Hydraulic Engineering, JSCE, 45, pp. 91-96.

Nguyen, L.T., and Tran, T.X. (2000) : "Some onedimensional unsteady flow models for river hydraulic calculation." Scientific and Technical Hydrometeorological Journal, 473, pp. 21-26 (in Vietnamese).

Ping, P., and Xiaofang, R. (1999) : "Method of flood routing in multibranch rivers." $J$. of Hydraulic Engineering, ASCE, 125 , pp. 271-276.

Ponce, V.M. (1994) : Engineering Hydrology:Principles and Practices, Prentice Hall.

Scheidegger, A.E. (1970) : Theoretical Geomorphology, Springer-Verlag.

Singh, V.P (1988) : Hydrologic Systems, 1 RainfallRunoff Modeling, Prentice Hall.

Strelkoff, T.S., and Falvey, H.T. (1993) : "Numerical methods used to model unsteady canal flow." $J$. of Irrigation and Drainage Engineering, ASCE, 119 , pp. 637-655.

USACE (US Army Corps of Engineers) - Hydrologic Engineering Center (2000): Hydrologic Modeling System HEC-HMS, Technical Reference Manual.

Yen, B.C. (1992) : "Hydraulic resistance in open channels." Channel Flow Resistance-Centennial of Manning's Formula, B.C. Yen, ed, Water Res. Publ., pp. 1-135.

(Received: Aug. 1, 2001, Accepted: Dec. 27, 2001) 